\title{
A Panel Data Analysis Of The Lucas Hypothesis
}

Mohammad Ashraf, (E-mail: mohammad.ashraf@uncp.edu), University of North Carolina at Pembroke Khan A. Mohabbat, (E-mail: kmohabbat@niu.edu), Northern Illinois University

\begin{abstract}
In this study we have attempted to verify one of the implications of the Lucas (1973) hypothesis using two-digit industry-level panel data for the U.S. Manufacturing Sector. The hypothesis states that the higher the nominal demand volatility, the lower will be the impact of nominal changes on real variables. Unlike other studies, we use disaggregated panel data for nineteen industries, which are scattered throughout the country, and are subject to the same fiscal and monetary shocks. Another unique feature of this study is the use of price level data at the two-digit industrylevel. As opposed to the use of overall price level data, which is common in the literature, we make use of the price level data at the two-digit industry-level. The results of our study support the Lucas hypothesis. Industries with low relative demand volatility transmit the effects of nominal demand shocks exclusively to output and industries with high relative volatility pass on the shocks directly to prices.
\end{abstract}

Finally, we tested for the relation between the real impact of the nominal aggregate disturbances and the relative volatility of industry demands. Our results show strong negative relation between them. That is, the higher the nominal demand volatility facing an industry, the less its impact would be on real output.

\section{Introduction}

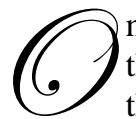

ne of the most important implications of the Lucas (1973) hypothesis is that the more frequently the authorities use demand shocks to stimulate output and employment the less successful they would be in their effort. That is, the variance of the nominal demand shocks and the impact of these shocks on real variables are negatively related. As a result, the higher volatility of the nominal demand disturbance would be transmitted more to inflation rather than output.

A number of papers have tested various implications of the Lucas (1973) hypothesis without reaching any consensus. Various studies have been carried out at the aggregate level using cross-country data. These studies include Sargent and Wallace (1975), Barro (1977, 1978), Barro and Rush (1980), Mishkin (1983), Kormendi and Meguire (1984), Kremtzer (1989), and Barro and Sala-i-Martin (1995). The results of these studies are sensitive to the data, data period, and the way the variables are constructed and the manner in which the analyses are carried out.

The validity of the Lucas hypothesis becomes even more significant in view of the unprecedented economic boom of the late 1990s followed by a slowdown in economic activity in the early 2000s in the United States. The substantial rise in financial asset prices and the roller coaster fluctuations in the stock market, resulted in an active role by the monetary authorities to suppress the "irrational exuberance" in financial asset pricing and slowdown the real sector to keep inflation under control. As the economic figures later pointed out that although the Fed was able to keep inflation under control, tightening of monetary policy probably also led to a decline in output. These economic changes alone warrant an effort to update and expand the existing research. In this study we test the above implication of the Lucas (1973) hypothesis using two-digit industry-level data for the U.S. Manufacturing Sector for 1977-99. Details are discussed in the data section of the paper.

Readerswith comments or questions are encouraged to contact the authors via email. 
This paper differs from the existing literature in two important ways: First, we use disaggregated industrylevel data for a single country, the United States. ${ }^{1}$ The U.S. Manufacturing Sector provides a setting that meets the requirements of the basic assumption of the Lucas hypothesis in which producers are scattered in competitive markets and the demand for each good is distributed unevenly over the markets. All industries in a single country are subject to the same fiscal and monetary shocks. Such is not the case for cross-country studies, where different countries have different monetary and fiscal authorities that are seldom subject to the same shocks at the same time. In addition, it is highly unlikely that most countries are subject to similar competitive market conditions. Secondly, unlike Lucas and others, we made use of the ARIMA models in our estimation process instead of the OLS. ${ }^{2}$ Using the OLS, the results indicated the presence of the first-order autocorrelation. We further verify our results by making use of panel data.

Our findings show that the effects of the nominal demand disturbance on real variables are not uniformly distributed over all industries. More specifically, eleven of the nineteen industries exhibit the effect of nominal demand disturbance either in output or prices, depending on the relative variation of the demand shock they face. Those industries with lower coefficients of variation than the industry-wide mean, channel the change in nominal demand to output only; whereas, those with higher coefficients of variation relative to the manufacturing sector mean increase prices only. These industries are behaving in accordance with the Lucas Hypothesis. Another six industries transmit the effect of the nominal demand shocks to both output and prices. In the remaining two industries the price effect and output effect of the nominal demand shocks have not been found. However, for all industries in the Manufacturing Sector, we have found a strong negative relationship between the real impact of nominal demand disturbance and the corresponding nominal demand volatility. Our last mentioned results are consistent with those of the previous findings using the cross-country data. Please see Ball, Mankiw, and Romer (1988).

The organization of the paper is as follows: Part II sets out the methodology used, Part III deals with data and data sources, Part IV discusses the results and Part V states the conclusions.

\section{Methodology}

In testing the relationship between the variance of the nominal shocks and the impact of these shocks on real output and price level, we follow the Lucas (1973) methodology. While the reader is referred to Lucas (1973) for complete details of the methodology, here we present some of the salient features of the model.

The model assumes that suppliers are located in a large number of scattered, competitive markets and the demand for each good is distributed unevenly over markets. This assumption gives rise to the relative price as well as general price level movements. Since markets are scattered, a single supplier in a particular market may view the price movements differently than an outsider. The supply in a single market is assumed to be the sum of two components: a secular component or a trend-line, which is affected by the economy-wide movements, and a cyclical component, which is market specific. Using the Lucas (1973) notation, the supply equation in market $\mathrm{z}$ takes the following form: ${ }^{3}$

$\mathrm{y}_{\mathrm{t}}(\mathrm{z})=\mathrm{y}_{\mathrm{nt}}+\mathrm{y}_{\mathrm{ct}}(\mathrm{z})$

where $\mathrm{y}_{\mathrm{t}}(\mathrm{z})$ represents the $\log$ of real output supplied in market $\mathrm{z}$ at time $\mathrm{t}, \mathrm{y}_{\mathrm{nt}}$ is the log of the secular component of real output, and $\mathrm{y}_{\mathrm{ct}}(\mathrm{z})$ is the log of the cyclical component of real output supplied. The secular component of real output supplied is a function of time as: ${ }^{4}$

$\mathrm{y}_{\mathrm{nt}}=\alpha+\beta \mathrm{t}$

The cyclical component of supply in market $\mathrm{z}$ depends upon the relative prices and its own lagged value and is market specific:

$\mathrm{y}_{\mathrm{ct}}(\mathrm{z})=\gamma\left[\mathrm{P}_{\mathrm{t}}(\mathrm{z})-\mathrm{E}\left(\mathrm{P}_{\mathrm{t}} \mid \mathrm{I}_{\mathrm{t}}(\mathrm{z})\right)\right]+\lambda \mathrm{y}_{\mathrm{c}, \mathrm{t}-1}(\mathrm{z})$ 
where $\mathrm{P}_{\mathrm{t}}(\mathrm{z})$ is the $\log$ of the actual price level in market $\mathrm{z}$ at time $\mathrm{t}, \mathrm{E}\left(\mathrm{P}_{\mathrm{t}} \mid \mathrm{I}_{\mathrm{t}}(\mathrm{z})\right)$ is the expected value of the $\log$ of overall price level based on the information available in market $\mathrm{z}$ at time $\mathrm{t}, \mathrm{I}_{\mathrm{t}}(\mathrm{z})$, and $|\lambda|<1$.

The aggregate demand function is:

$y_{t}+P_{t}=x_{t}$

where $y_{t}$ is the $\log$ real output, $P_{t}$ is the $\log$ of overall price level, and $x_{t}$ is the log of nominal GDP and serves as an exogenous shift variable.

Summing and averaging over markets and solving the model we get:

$\mathrm{y}_{\mathrm{ct}}=-\pi \delta+\pi \Delta \mathrm{x}_{\mathrm{t}}+\lambda \mathrm{y}_{\mathrm{c}, \mathrm{t}-1}$

$\Delta \mathrm{P}_{\mathrm{t}}=-\beta+(1-\pi) \Delta \mathrm{x}_{\mathrm{t}}+\pi \Delta \mathrm{x}_{\mathrm{t}-1}-\lambda \Delta \mathrm{y}_{\mathrm{c}, \mathrm{t}-1}$

Equations (5) and (6) are the equilibrium values of the log of real output and the inflation rate "(as a percentage deviation from trend)" at time t. We would expect the estimated values $\pi$ of and $\lambda$ in Equations (5) and (6) to be between zero and one. ${ }^{5}$

Lucas (1973) used data from eighteen countries to see if the value of $\pi$ declines as the sample variance of $\Delta \mathrm{x}_{\mathrm{t}}$ increases and the nominal demand shock translates into increased inflation rate. In this study we extend the Lucas hypothesis to the industry-level and attempt to verify whether the shock effect of an increase in the sample variance of the nominal output, $\Delta \mathrm{x}_{\mathrm{t}}$, of a particular industry is transmitted more to real output or to the price level.

\section{Data}

\begin{tabular}{|ll|}
\hline \multicolumn{1}{c|}{ Table 1: List of Industries } \\
\hline SIC & $\begin{array}{l}\text { Industry Name } \\
\text { (Industry description defined on the 1987-SIC basis) }\end{array}$ \\
& \\
\hline 20 & Food and Kindred Products \\
21 & Tobacco Products \\
22 & Textile Mil Products \\
23 & Apparel and Other Products \\
24 & Lumber and Wood Products \\
25 & Furniture and Fixture \\
26 & Paper and Allied Products \\
27 & Printing and Publishing \\
28 & Chemical and Allied Products \\
29 & Petroleum and Coal Products \\
30 & Rubber and Miscellaneous Plastics Products \\
31 & Leather and Leather Products \\
32 & Stone, Clay, and Glass Products \\
33 & Primary Metal Industries \\
34 & Fabricated Metal Industries \\
35 & Industrial Machinery and Equipment \\
371 & Motor Vehicles and Equipment \\
$372-9$ & Other Transportation Equipment \\
39 & Miscellaneous and Related Products \\
& \\
\hline Note: & The statistical analysis for this study was done in early \\
2002. & At the time, price level data for Electronic and Other \\
Electric Equipment (SIC 36) and Instruments and Related \\
Products (SIC 38) for 1977-86 were not available. So these \\
two industries were not included in the analysis. \\
\hline
\end{tabular}

In this study we use two-digit industry-level annual data for the U.S. Manufacturing Sector (1987 SIC industrial classification) for 1977-1999. In order to conduct panel analysis we used three-step approach. ${ }^{6}$ First, using Equation (2) we ran regressions for each industrial classification to dichotomize the cyclical and secular components, $\mathrm{y}_{\mathrm{ct}}$ and $\mathrm{y}_{\mathrm{n}}$, respectively. These cyclical components of real gross product originating (GPO) for each industrial classification along with nominal GPO and industry-level pricelevel data were combined to form a panel. This panel was later used to run regressions using Equations (5) and (6). In the process of calculating growth rates of GPO, $\Delta \mathrm{x}_{\mathrm{t}}$, and its lag, $\Delta \mathrm{x}_{\mathrm{t}-1}$, the cyclical component of GPO, $y_{\mathrm{ct}}$, its growth rate, $\Delta \mathrm{y}_{\mathrm{ct}}$, and its lag, $\Delta \mathrm{y}_{\mathrm{c}, \mathrm{t}-1}$, which was used in Equation (6), the growth rate of price-level, $\Delta \mathrm{P}_{\mathrm{t}}$, the dependent variable in Equation (6), we lost three observations. This left us with a panel of nineteen industries and twenty years (19801999). So our panel has nineteen cross-sectional units and twenty time series units.

The U.S. Department of Commerce, Bureau of Economic Analysis, Industry Economics Division provides data for nominal output as Gross Product Originating (GPO). We use the GPO data to obtain the nominal output values, $x_{t}$, for Equations (5) and (6). The Department of Commerce, Bureau of Economic 
Analysis also provides price level data at the two-digit industry-level. These data are used in Equation (6) for the price level, P. Both the price level data and the GPO were used to convert the nominal output into real output for each industry. A list of these industries is provided in Table 1. To get the cyclical component of the real output, $\mathrm{y}_{\mathrm{ct}}$, we deduct the trend-line output, $y_{n t}$, from the observed real output, $y_{t}$, for each industry. That is: $y_{\mathrm{ct}}=y_{t}-y_{n t}$.

However, to properly compare industries with one another we use a relative dispersion measure, the coefficient of variation (CV) of the Gross Product Originating, rather than the commonly used absolute measure, the va-

riance. The coefficient of variation used here is defined as $\frac{S}{\bar{X}}$, where $\mathrm{S}$ is the sample standard deviation and $\bar{X}$ is the sample mean of a particular industry. For comparison purposes, this measure is superior to the simple variance, since it represents dispersion as a percentage of the mean. That is, CV represents a relative volatility differential among industries. In our analysis, CV ranged from 0.1297 for Leather and Leather Products (SIC 31) to 0.4392 for Chemical and Allied Products (SIC 28), with an industry-wide mean of 0.2928. We consider CV, in a particular industry, to be high if its value was greater than the manufacturing industry-wide mean CV, 0.2928, low if the value fell below the mean and equal if it was in the vicinity of the industry-wide mean CV.

\section{Discussion of the Results}

\subsection{Time Series Analysis}

Interestingly, the results for the nineteen industries show large variations when subjected to nominal demand disturbances. We classify our findings into three categories. The classification is based on the response of the different industries to nominal demand shocks. That is, industries that have responded to nominal demand shocks by adjusting either output or prices alone are put in one category. Industries that have responded to nominal demand shocks with both price and output changes are set in the next group. Industries that have not responded with either price and/or output changes to the nominal disturbance are placed in the last classification. Table 2 presents the results for the first group of industries. ${ }^{7}$ Due to space limitations we only present coefficient estimates along with tvalues. Detailed ARIMA results are available from the authors. ${ }^{8}$

Our findings show that six of the nineteen industries with CV's less than or within the vicinity of the industry wide mean follow the Lucas hypothesis prescription. That is, industries where the relative dispersion of the nominal demand shock is low, the impact of a nominal shock is passed on to output and not to prices. The six industries that fit this description are the Food and Kindred Products (SIC 20), Textile Mil Products (SIC 22), Stone, Clay and Glass Products (SIC 32), Fabricated Metal Products (SIC 34), Machinery except Electrical (SIC 35), and Other Transportation Equipment (SIC372-379). The CV values of the Food and Kindred Products (SIC20) and Other Transportation Equipment (372-379) are slightly higher than the industry-wide CV of 0.2927, but difference is less than one-fourth of the industry wide standard deviation of 0.0803 . The $\pi$ estimates, which relate changes in the nominal industry output to the cyclical components, $y_{\mathrm{ct}}$, are all significant at the $95 \%$ or higher confidence level. Only the Miscellaneous Manufacturing Industries (SIC 39) with a CV somewhat greater than the industry wide mean does not seem to conform to the hypothesis. Contrary to the hypothesis, the impact of the nominal shock is felt exclusively by output, not prices. Looking at this industry more closely, the CV of the Miscellaneous Manufacturing Industries deviates from the industry-wide mean by only three-fourth of the industry wide standard deviation.

With regard to nominal shocks affecting prices only, there are four industries with CVs greater than the industry-wide mean that fit this criterion. They are the Tobacco Products (SIC 21) and Paper and Allied Products (SIC 26), Printing and Publishing (SIC 27), and Chemical and Allied Products (SIC 28).

The estimate of (1- $\pi$ ) in (SIC 26), and the estimates of $\pi$ and (1- $\pi$ ) in (SIC 21) industries are significant at the $99 \%$ level. The estimates of (1- $\pi$ ) and $\pi$ in the price equations of the last two industries, (SIC 27) and (SIC 28) respectively, are somewhat short of being significant at the 95\% level. However, they are significant at the $90 \%$ level. In line with the Lucas hypothesis, these four industries transmit the impact of the nominal demand shock solely to prices and not to output. 
Table 2: Regression Results-Equations (2), (5) and (6) [11 Industries]

\begin{tabular}{|c|c|c|c|c|c|c|c|c|}
\hline \multirow{2}{*}{\multicolumn{2}{|c|}{\begin{tabular}{|l|} 
\\
SIC CV \\
\end{tabular}}} & \multirow{2}{*}{ (2) $y_{n t}=\alpha+\beta t$} & \multicolumn{2}{|c|}{ (5) $\mathrm{y}_{\mathrm{ct}}=-\pi \delta+\pi \Delta \mathrm{x}_{\mathrm{t}}+\lambda \mathrm{y}_{\mathrm{c}, \mathrm{t}-1}$} & \multicolumn{4}{|c|}{ (6) $\Delta \mathrm{P}_{\mathrm{t}}=-\beta+(1-\pi) \Delta \mathrm{x}_{\mathrm{t}}+\pi \Delta \mathrm{x}_{\mathrm{t}-1}-\lambda \Delta \mathrm{y}_{\mathrm{ct}, \mathrm{t}}$} \\
\hline & & & $(\pi \delta)^{\wedge}$ & $\lambda^{\wedge}$ & $\beta^{\wedge}$ & $(1-\pi)^{\wedge}$ & $\pi^{\wedge}$ & $\lambda^{\Lambda}$ \\
\hline & 0.31 & $\begin{array}{rr}- & 0.0009 \\
(.77)\end{array}$ & $\begin{array}{l}0.6^{\mathrm{a}} \\
(2.9)\end{array}$ & $\begin{array}{l}-0.25 \\
(1.35)\end{array}$ & $\begin{array}{l}0.005 \\
(.32)\end{array}$ & $\begin{array}{l}-0.06 \\
(0.22)\end{array}$ & $\begin{array}{c}0.51 \\
(1.62)\end{array}$ & $\begin{array}{r}-0.28 \\
(1.09)\end{array}$ \\
\hline 22 & 0.22 & $\begin{array}{r}-\quad 0.0003^{\mathrm{c}} \\
(1.86)\end{array}$ & $\begin{array}{l}0.749^{\mathrm{a}} \\
(6.27)\end{array}$ & $\begin{array}{r}-0.065 \\
(0.47)\end{array}$ & $\begin{array}{c}0.009 \\
(0.74)\end{array}$ & $\begin{array}{r}0.205 \\
(1.41)\end{array}$ & $\begin{array}{l}-0.106 \\
(0.46)\end{array}$ & $\begin{array}{r}0.115 \\
(0.93)\end{array}$ \\
\hline 32 & 0.22 & $\begin{array}{r}-\quad 0.000 \\
\quad(.47)\end{array}$ & $\begin{array}{r}-\quad 0.934^{\mathrm{a}} \\
-\quad(11.59)\end{array}$ & $\begin{array}{l}-0.141^{\mathrm{c}} \\
(1.82)\end{array}$ & $\begin{array}{l}0.024^{c} \\
(1.86)\end{array}$ & $\begin{array}{l}0.004 \\
(0.05)\end{array}$ & $\begin{array}{r}0.090 \\
(0.71)\end{array}$ & $\begin{array}{r}0.012 \\
(0.18)\end{array}$ \\
\hline 34 & 0.28 & $\begin{array}{l}0.000^{\mathrm{c}} \\
(1.79)\end{array}$ & $\begin{array}{cc}-0.055^{\mathrm{a}} & 1.117^{\mathrm{a}} \\
(6.07) & (8.31)\end{array}$ & $\begin{array}{l}-0.137 \\
(1.24)\end{array}$ & $\begin{array}{l}0.02^{\mathrm{c}} \\
(1.74)\end{array}$ & $\begin{array}{r}-0.154 \\
(1.17)\end{array}$ & $\begin{array}{r}0.218 \\
(1.55)\end{array}$ & $\begin{array}{r}-0.034 \\
(0.39)\end{array}$ \\
\hline 35 & 0.27 & $\begin{array}{r}-0.0002^{\mathrm{a}} \\
(3.17)\end{array}$ & $\begin{array}{ll}-\quad 1.009^{\mathrm{a}} \\
(7.56)\end{array}$ & $\begin{array}{r}-0.395^{\mathrm{a}} \\
(3.50)\end{array}$ & . & $\begin{array}{l}-0.109 \\
(.76)\end{array}$ & $\begin{array}{r}0.043 \\
(0.28)\end{array}$ & $\begin{array}{l}0.059 \\
(0.74)\end{array}$ \\
\hline 372 & -90.31 & $\begin{array}{r}-\quad 0.00 \\
-\quad(0.20)\end{array}$ & $\begin{array}{l}0.593^{\mathrm{a}} \\
(4.55)\end{array}$ & $\begin{array}{r}-0.004 \\
(0.02)\end{array}$ & $\begin{array}{l}0.048^{\mathrm{a}} \\
(3.73)\end{array}$ & $\begin{array}{c}0.163 \\
(1.56)\end{array}$ & $\begin{array}{l}-0.079 \\
(0.53)\end{array}$ & $\begin{array}{l}0.051 \\
(0.43)\end{array}$ \\
\hline 39 & 0.34 & $\begin{array}{l}0.000 \\
(0.99)\end{array}$ & $\begin{array}{l}0.591^{\mathrm{b}} \\
(2.87)\end{array}$ & $\begin{array}{l}0.071 \\
(0.35)\end{array}$ & $\begin{array}{l}0.017 \\
(.58)\end{array}$ & $\begin{array}{l}-0.029 \\
(0.13)\end{array}$ & $\begin{array}{l}0.281 \\
(0.83)\end{array}$ & $\begin{array}{l}-0.154 \\
(0.95)\end{array}$ \\
\hline 26 & 0.34 & $\begin{array}{r}0.00 \\
(1.30)\end{array}$ & $\begin{array}{l}-0.11 \\
(0.54)\end{array}$ & $\begin{array}{r}-0.005 \\
(0.02)\end{array}$ & $\begin{array}{r}-0.039 \\
(1.46)\end{array}$ & $\begin{array}{l}1.316^{\mathrm{a}} \\
(4.40)\end{array}$ & $\begin{array}{c}0.185 \\
(0.51)\end{array}$ & $\begin{array}{l}-0.148 \\
(0.67)\end{array}$ \\
\hline 21 & 0.35 & $\begin{array}{r}-0.001 \\
(1.52)\end{array}$ & $\begin{array}{l}0.126 \\
(0.41)\end{array}$ & $\begin{array}{c}0.195 \\
(0.84)\end{array}$ & $\begin{array}{r}0.0007 \\
(0.03)\end{array}$ & $\begin{array}{l}0.87^{\mathrm{a}} \\
(2.97)\end{array}$ & $\begin{array}{l}1.054^{\mathrm{a}} \\
(3.61)\end{array}$ & $\begin{array}{l}-0.381^{\mathrm{b}} \\
(2.33)\end{array}$ \\
\hline 27 & 0.38 & $\begin{array}{l}0.000 \\
(0.80)\end{array}$ & $\begin{array}{l}0.149 \\
(1.57)\end{array}$ & $\begin{array}{l}0.16 \\
(0.73)\end{array}$ & $\begin{array}{r}0.041^{\mathrm{a}} \\
(3.12)\end{array}$ & $\begin{array}{l}0.323^{\mathrm{c}} \\
(2.02)\end{array}$ & $\begin{array}{l}-0.004 \\
(0.02)\end{array}$ & $\begin{array}{c}-0.098 \\
(0.65)\end{array}$ \\
\hline 28 & 0.44 & $\begin{array}{r}0.0001^{\mathrm{b}} \\
(2.30)\end{array}$ & $\begin{array}{c}0.209 \\
(1.45)\end{array}$ & $\begin{array}{l}-0.107 \\
(0.47)\end{array}$ & $\begin{array}{c}-0.016 \\
(.67)\end{array}$ & $\begin{array}{c}0.287 \\
(1.37)\end{array}$ & $\begin{array}{l}0.497^{\mathrm{c}} \\
(2.02)\end{array}$ & $\begin{array}{r}-0.140 \\
(0.98)\end{array}$ \\
\hline
\end{tabular}

Significance Level: ${ }^{c}=90 \%,{ }^{b}=95 \%,{ }^{a}=99 \%$. t-values in parentheses. "^" stands for the estimate of the respective parameter.

The effects of nominal demand disturbance on prices are not uniform for these industries. For instance, the impact of the nominal shocks on prices for (SIC 21) comes from the current disturbances in nominal demand, $\Delta \mathrm{x}_{\mathrm{t}}$, and lagged shocks, $\Delta \mathrm{x}_{\mathrm{t}-1}$. In industries (SIC 26) and (SIC 27) only the contemporaneous demand shocks, $\Delta \mathrm{x}_{\mathrm{t}}$, are responsible for price changes. In industry (SIC 28), it is the lagged demand shock, $\Delta \mathrm{x}_{\mathrm{t}-1}$, that affects prices. If we do not accept the $90 \%$ confidence level, then the Printing and publishing industry (SIC 27) and Chemical and Allied Products (SIC 28) do not strictly support the Lucas Hypothesis. However, closer examination reveals that in the Printing and Publishing industry only the exogenous intercept term, $\beta$, is significant in the price equation. Our findings imply an inelastic (vertical) industry supply curve for Printing and Publishing industry. These results are partially supported by studies showing occasional price changes in the newspaper and magazine industries. Please see Cecchetti (1986).

For the Chemical and Allied Products (SIC 28) industry only the coefficient estimate of $\beta$ in the secular output equation is positive and significant at the $95 \%$ confidence level. This in turn implies that the Chemical and Allied Products industry does not have the pricing power and face an elastic (horizontal) industry supply curve.

In the second category, there are six industries where nominal demand shocks affect both prices and output. The joint price-output response holds irrespective of whether the industry CVs are above or below the industry-wide mean. The results are presented in Table 3 . 
Table 3: Regression Results-Equations (2), (5) and (6) [6 Industries]

\begin{tabular}{|c|c|c|c|c|c|c|c|c|c|c|}
\hline & & (2) $y_{1}$ & $=\alpha+\beta \mathrm{t}$ & $(5) \mathrm{y}_{\mathrm{ct}}=$ & $=-\pi \delta+\pi$ & $\mathrm{x}_{\mathrm{t}}+\lambda \mathrm{y}_{\mathrm{c}, \mathrm{t}-1}$ & (6) $\Delta P_{t}$ & $-\beta+(1-\pi)$ & $+\pi \Delta x_{t-1}$ & $\lambda \Delta \mathrm{y}_{\mathrm{c}, \mathrm{t}-1}$ \\
\hline SIC & $\mathrm{CV}$ & $\alpha^{\wedge}$ & $\beta^{\wedge}$ & $(\pi \delta)^{\wedge}$ & $\pi^{\wedge}$ & $\lambda^{n}$ & $\beta^{\wedge}$ & $(1-\pi)^{\wedge}$ & $\pi^{\wedge}$ & $\lambda^{\wedge}$ \\
\hline 371 & 0.34 & - & $\begin{array}{r}-2.29 \mathrm{E}-6 \\
(.02)\end{array}$ & - & $\begin{array}{l}0.896^{\mathrm{a}} \\
(11.24)\end{array}$ & $\begin{array}{l}0.130 \\
(1.58)\end{array}$ & $\begin{array}{l}0.047^{\mathrm{a}} \\
(4.19)\end{array}$ & $\begin{array}{r}0.092 \\
(1.23)\end{array}$ & $\begin{array}{r}-0.247^{b} \\
(2.36)\end{array}$ & $\begin{array}{l}0.171^{\mathrm{c}} \\
(2.06)\end{array}$ \\
\hline 25 & 0.33 & _ & $\begin{array}{r}-0.0002^{\mathrm{b}} \\
(2.23)\end{array}$ & - & $\begin{array}{l}0.392^{\mathrm{b}} \\
(2.49)\end{array}$ & $\begin{array}{l}-0.059 \\
(0.29)\end{array}$ & $\begin{array}{l}0.076^{\mathrm{a}} \\
(3.79)\end{array}$ & $\begin{array}{l}-0.277^{\mathrm{a}} \\
(2.90)\end{array}$ & $\begin{array}{c}0.322^{a} \\
(3.39)\end{array}$ & $\begin{array}{l}-0.135^{\circ} \\
(2.04)\end{array}$ \\
\hline 24 & 0.29 & - & $\begin{array}{r}-0.0001 \\
(0.36)\end{array}$ & - & $\begin{array}{l}0.458^{\mathrm{a}} \\
(3.98)\end{array}$ & $\begin{array}{r}-0.023 \\
(0.13)\end{array}$ & $\begin{array}{l}0.013 \\
(0.57)\end{array}$ & $\begin{array}{l}0.448^{\mathrm{a}} \\
(3.55)\end{array}$ & $\begin{array}{r}-0.124 \\
(0.91)\end{array}$ & $\begin{array}{r}-0.066 \\
(0.52)\end{array}$ \\
\hline 29 & 0.28 & - & $\begin{array}{r}-0.0001 \\
(0.82)\end{array}$ & - & $\begin{array}{l}0.313^{\mathrm{b}} \\
(2.33)\end{array}$ & $\begin{array}{r}-0.076 \\
(0.38)\end{array}$ & - & $\begin{array}{l}0.894^{\mathrm{a}} \\
(4.00)\end{array}$ & $\begin{array}{l}0.314^{\mathrm{c}} \\
(1.91)\end{array}$ & $\begin{array}{r}-0.104 \\
(0.62)\end{array}$ \\
\hline 31 & 0.13 & - & $\begin{array}{r}-0.00 \\
(1.48)\end{array}$ & - & $\begin{array}{l}0.646^{\mathrm{a}} \\
(6.06)\end{array}$ & $\begin{array}{c}0.170 \\
(1.21)\end{array}$ & $\begin{array}{l}0.023^{\mathrm{a}} \\
(8.39)\end{array}$ & $\begin{array}{l}0.222^{\mathrm{a}} \\
(5.22)\end{array}$ & $\begin{array}{r}0.065 \\
(1.20)\end{array}$ & $\begin{array}{r}-0.044 \\
(0.79)\end{array}$ \\
\hline 33 & 0.15 & - & $\begin{array}{r}-0.00 \\
(0.16)\end{array}$ & - & $\begin{array}{l}0.686^{\mathrm{a}} \\
(6.84)\end{array}$ & $\begin{array}{r}-0.139 \\
(1.05)\end{array}$ & - & $\begin{array}{l}0.296^{\mathrm{b}} \\
(2.79)\end{array}$ & $\begin{array}{c}0.175 \\
(1.37)\end{array}$ & $\begin{array}{r}-0.091 \\
(0.88)\end{array}$ \\
\hline
\end{tabular}

Significance Level: ${ }^{c}=90 \%,{ }^{b}=95 \%,{ }^{a}=99 \%$. t-values in parentheses. “^” stands for the estimate of the respective parameter.

The two industries, Motor Vehicles and Equipment (SIC 371) and Furniture and Fixture (SIC 25), with CV's greater than the industry-wide mean not only show increases in prices due to nominal demand shocks but also increases in output. The coefficient estimates of the nominal demand shocks of the cyclical output and price equations for these two industries are significant at the $95 \%$ level or above. The remaining four industries, Lumber and Wood Products (SIC 24), Petroleum and Coal Products (SIC 29), Leather and Leather Products (SIC 31) and Primary Metal Industries (SIC 33), with CVs less than the industry-wide mean also transmit the nominal demand shocks to output as well as to prices. The coefficient estimates of $\Delta \mathrm{x}_{\mathrm{t}}$ with or without lags in the cyclical output and price equations are highly significant. The behavior of these six industries either partially support or reject the Lucas hypothesis, depending on one's point of view.

Finally, there are two industries with CV's either greater or smaller than the industry-wide mean that exhibit no influence on output or prices due to nominal demand shocks. The results are presented in Table 4.

Table 4: Regression Results-Equations (2), (5) and (6) [2 Industries]

\begin{tabular}{|c|c|c|c|c|c|c|c|c|c|}
\hline \multirow[b]{2}{*}{ SIC CV } & \multicolumn{2}{|c|}{ (2) $\mathrm{y}_{\mathrm{nt}}=\alpha+\beta \mathrm{t}$} & \multicolumn{3}{|c|}{ (5) $\mathrm{y}_{\mathrm{ct}}=-\pi \delta+\pi \Delta \mathrm{x}_{\mathrm{t}}+\lambda \mathrm{y}_{\mathrm{c}, \mathrm{t}-1}$} & \multicolumn{4}{|c|}{ (6) $\Delta \mathrm{P}_{\mathrm{t}}=-\beta+(1-\pi) \Delta \mathrm{x}_{\mathrm{t}}+\pi \Delta \mathrm{x}_{\mathrm{t}-1}-\lambda \Delta \mathrm{y}_{\mathrm{c}, \mathrm{t}-1}$} \\
\hline & $\alpha^{\wedge}$ & $\beta^{\wedge}$ & $(\pi \delta)^{\wedge}$ & $\pi^{\wedge}$ & $\lambda^{\wedge}$ & $\beta^{\wedge}$ & $(1-\pi)^{\wedge}$ & $\pi^{\wedge}$ & $\lambda^{\wedge}$ \\
\hline $23 \quad 0.19$ & - & $\begin{array}{l}0.0002^{\mathrm{a}} \\
(8.82)\end{array}$ & - & $\begin{array}{l}0.244 \\
(1.54)\end{array}$ & $\begin{array}{l}-0.271 \\
(1.34)\end{array}$ & $\begin{array}{l}0.015 \\
(0.73)\end{array}$ & $\begin{array}{l}0.103 \\
(0.29)\end{array}$ & $\begin{array}{r}-0.034 \\
(0.11)\end{array}$ & $\begin{array}{r}-0.059 \\
(0.31)\end{array}$ \\
\hline $\begin{array}{ll}30 & 0.38\end{array}$ & - & $\begin{array}{l}0.0003^{\mathrm{a}} \\
(5.59)\end{array}$ & - & $\begin{array}{l}0.237 \\
(1.65)\end{array}$ & $\begin{array}{l}-0.155 \\
(0.69)\end{array}$ & - & $\begin{array}{r}-0.029 \\
(0.23)\end{array}$ & $\begin{array}{l}0.062 \\
(0.45)\end{array}$ & $\begin{array}{r}-0.102 \\
(0.91)\end{array}$ \\
\hline
\end{tabular}

Significance Level: ${ }^{c}=90 \%,{ }^{b}=95 \%,{ }^{a}=99 \%$. t-values in parentheses. " $\wedge$ " stands for the estimate of the respective parameter.

The industries exhibiting such behavior are the Apparel and Other Textile Products (SIC 23) and Rubber and Miscellaneous Plastic Products (SIC 30). The Apparel and Other Textile Products possesses a CV value that is below the industry-wide mean and the Rubber and Miscellaneous Plastic Products industry has a CV that is greater than the industry-wide mean. In neither case the demand shocks influence real output or prices. The rise in real output in the Apparel and Other Textile Products and Rubber and Miscellaneous Plastic Products industries is only due to the secular component of the real output and not due to the cyclical component. The coefficient estimates of $\beta$ in the secular output equations, Equation (2), are significant at the $99 \%$ level for both industries. No other coefficient in the output or price equations is significant at any reasonable level. Our results suggest that the Apparel and Other Textile Products and the Rubber and Miscellaneous Plastic Products industries do not have the pricing power. This in turn implies that both industries face elastic (horizontal) industry supply curves. 
Finally we wish to test the relation between the real impact of the nominal disturbances, $\pi$, of the industries and their coefficients of variation, CV. A cursory observation reveals that there are sizable differences among the $\pi$ 's and CV's of various industries. The assessment of the test result is important, since not all industries have pursued the hypothesized path even though the majority of the industries have followed the Lucas hypothesis. It is usually argued that when nominal demand disturbances increase, they often lead firms to uncertainty. The higher the volatility of nominal demand the more uncertain the firms become with regard to the nature of the volatility. Uncertainty breeds conservatism wherein the firms may pass on the nominal demand shocks more to prices than to output. For the nineteen industries studied, the regression results are:

$$
\pi_{\mathrm{t}}=\begin{array}{lc}
1.21 * * * & -22.68 * * \mathrm{CV} \\
(4.88) & (2.89)
\end{array}
$$

F-value $=8.35, R^{2}($ adj. $)=0.29$

where $\pi_{\mathrm{t}}$ represents the real impact of the aggregate demand disturbance, and CV is the coefficient of variation, defined above. The $t$-values are in the parentheses.

Our results are significant at the $95 \%$ confidence level, showing a negative relation between the real impact of nominal demand disturbance, $\pi_{\mathrm{t}}$, and the corresponding demand volatility, $\mathrm{CV}$, of the industries. Our findings strongly suggest that the higher the nominal demand volatility facing an industry the less its impact would be on real output. Firms in the industry would adjust prices rather than output to keep up with inflation. Our findings are in line with those of Lucas (1973) and Ball, Mankiw and Romer (1988). This result is further verified with the use of panel data.

\subsection{Panel Data Analysis}

The use of panel data in the case of the Lucas hypothesis, by itself, does not make much sense. Recall that the Lucas hypothesis, in our case, implies that industries that have higher variance of nominal demand shocks will transmit a given shock to price level changes and not to output. On the other hand, industries that have lower volatility of nominal demand shocks will transmit shocks to output and not to price level changes. When we make use of panel data it does not throw any light on this aspect.

However, recall that results of some of the industries support the Lucas hypothesis whereas others do not. The use of panel data allows us to figure out if the mix of results was not just a fluke. This is established by looking at the estimated coefficients of the two equations: the output equation, Equation (5), and price-level equation, Equation (6). We estimated these equations using Random Effects models. In the case of both equations, the Hausman Test for Random Effects pointed out to the superiority of the Random Effects model over the Fixed Effects model. The regression results are (t-statistics in parentheses):

The Output Equation

\begin{tabular}{|c|c|c|c|c|}
\hline \multicolumn{5}{|c|}{$\Delta \mathrm{P}_{\mathrm{t}}=-\beta+(1-\pi) \Delta \mathrm{x}_{\mathrm{t}}+\pi \Delta \mathrm{x}_{\mathrm{t}-1}-\lambda \Delta \mathrm{y}_{\mathrm{c}, \mathrm{t}-1}$} \\
\hline$\Delta \mathrm{P}_{\mathrm{t}}=$ & $\begin{array}{l}0.012 \\
(1.11)\end{array}$ & $\begin{array}{l}+0.328 * * * \Delta \mathrm{x}_{\mathrm{t}} \\
(6.07)\end{array}$ & $\begin{array}{l}+0.125 * * \Delta \mathrm{x}_{\mathrm{t}-1} \\
(2.28)\end{array}$ & $\begin{array}{l}+0.046 \Delta \mathrm{y}_{\mathrm{c}, \mathrm{t}-1} \\
(1.41)\end{array}$ \\
\hline
\end{tabular}

$$
\begin{aligned}
& \begin{array}{lll}
\mathrm{y}_{\mathrm{ct}}=-\pi \delta+\pi \Delta \mathrm{x}_{\mathrm{t}}+\lambda \mathrm{y}_{\mathrm{c}, \mathrm{t}-1} \\
\hline \mathrm{y}_{\mathrm{ct}}=-0.027 * * * & +0.647 * * * \Delta \mathrm{x}_{\mathrm{t}} & -0.08^{*} \mathrm{y}_{\mathrm{c}, \mathrm{t}-1} \\
(-4.05) & (12.28) & (-1.81)
\end{array} \\
& \overline{\mathrm{R}^{2}}=0.29 ; \text { Hausman Test for Random Effects: } \mathrm{m} \text { value }=0.12 \text {; } \\
& \mathrm{p} \text {-value }=0.9432
\end{aligned}
$$

The Price-level Equation 
The coefficient estimates of the output and the price-level equations imply that nominal demand shocks affect both output and price-level. Note that the coefficient estimates of $\Delta \mathrm{x}_{\mathrm{t}}$ in both the output and the price-level equation add up, as they should, to approximately 1 . Coefficient estimates of $\Delta \mathrm{x}_{\mathrm{t}}$ in both equations are significant at the $99 \%$ level.

Note that if only the output equation had statistically significant results, we would conclude that no matter what the level of the variability of the nominal demand shocks, the output is affected. If, on the other hand, only the price-level equation had statistically significant results, we would conclude that nominal demand shocks only affect the price level regardless of the level of volatility. Since the panel data results indicate that both the output and the price-level equations carry significant results, this renders support to time series results. Furthermore, the estimated coefficient value of $\Delta \mathrm{x}_{\mathrm{t}}$ in the output equation is about twice the magnitude of the price-level equation. This implies that current nominal demand shocks translate more into output than into price-level changes.

\section{Concluding Remarks}

In this study we have attempted to verify one of the implications of the Lucas (1973) hypothesis. The hypothesis we tested states that the higher the nominal demand volatility in a market, the lower would be the impact of the nominal changes on real variables. Unlike other studies in the literature using aggregate cross-country data, we have used much more disaggregated data for nineteen industries of the United States Manufacturing Sector for the period of 1977-99. The U.S. Manufacturing Sector provides a setting that meets the requirements of the basic assumption of the Lucas (1973) hypothesis, in which producers are scattered in competitive markets and demand for goods is distributed unevenly over the markets. Furthermore, every industry in a single country is subject to the same shocks that are created by fiscal and monetary authorities.

Our results show that eleven of the nineteen manufacturing industries behave in line with the Lucas hypothesis. Those industries that have low relative volatility transmit the effect of nominal demand shocks exclusively to output. Industries with high relative volatility pass on the nominal demand shocks directly to prices and not to output. Two industries one with high and the other with low relative nominal demand volatility do not systematically pass on the effects of the demand shocks either to output or prices. These two industries do not subscribe to the Lucas hypothesis. Six industries irrespective of their relative nominal demand volatility transmit the effects of the demand shocks to both output and prices. The behavior of these six industries may either partially support or reject the Lucas hypothesis, depending on one's point of view.

Finally, we attempted to ascertain the relation between the real impact of nominal demand disturbances, and the relative dispersion of nominal demand shocks of the industries. Our results show a strong negative relation between them. That is, the higher the industry nominal demand volatility the less its impact would be on real output. Firms in the industry would adjust prices rather than output to keep up with inflation. We also verified our time series results using a panel data approach. The results of the panel data approach point to the robustness of the time series results. These results also point out that the impact of current nominal demand shocks translates more into output changes than into price-level changes.

\section{End Notes}

1 To our knowledge, only one study, Kremtzer (1989), makes use of the disaggregate data at the two-digit industry level. However the data period is 1948-77. In our study the data period is 1977-99.

2 In estimating Equations (2), (5), and (6) below, we used the ARIMA procedure. The models used were selected on the basis of Ljung-Box statistic ( $\left.Q^{*}\right)$, Akaike Information Criterion (AIC), and Schwarz Bayesian Information Criterion (SBC). See Bowerman and O'Connell (1993) for details.

3 Equations (1)-(6) below are Lucas (1973) Equations (1)-(3), (8), (11), and (12), respectively.

4 Although nonlinear filters, such as Hodrick-Prescott (1997) filter, have become popular in recent literature for detrending a time series, we use linear filter to stay consistent with Lucas (1973). 
5 See Lucas (1973), p. 330 for further explanation of this point.

6 Details on the rationale of using panel data are discussed later in the paper.

7 GPO data pointed to the presence of nonstationarity. In order to deal with that we first differenced the GPO data. We made use of Sample Autocorrelation Function (SAC) and Partial Sample Autocorrelation Function (SPAC) to determine stationarity of a series. See Bowerman and O'Connell (1993) for details.

8 We included an intercept term in the model if $\mu>0$. Where $\mu$ is the mean of all possible realizations of the stationary time series under consideration. To test to see if $\mu>0$, we calculated the statistic: $\frac{\bar{z}}{S_{z} / \sqrt{n-b+1}}$. The value of this statistic greater than 2 implies $\mu>0$. For further details see Bowerman and O'Connell (1993), Chapter 10.

\section{References}

1. Ball, Laurence, Mankiw, N. Gregory, and Romer, David (1988) "The New Keynesian Economics and Output-Inflation Trade-off," Brooking Papers on Economic Activity, No. 1, pp.1-65.

2. Barro, Robert J. (1977) "Unanticipated Money Growth and Unemployment in the United Sates," The American Economic Review, vol. 67, \# 2.

3. Barro, Robert J. (1978) "Unanticipated Money, Output, and the Price Level in the United States", Journal of Political Economy, vol. 86, \# 4.

4. 는 and Rush, Mark (1980) "Unanticipated Money and Economic Activity," Rational Expectations and Economic Policy, Ed. Stanley Fischer. The University of Chicago Press.

5. _ and Sala-i-Martin, Xavier (1995) Economic Growth, McGraw-Hill, Inc.

6. Bowerman, Bruce L., and O'Connell, Richard T. (1993) Forecasting and Time Series: An Applied Approach, $3^{\text {rd }}$ Ed., Duxbury Press.

7. Cecchetti, Stephen G. (1986) "The Frequency of Price Adjustment: A study of the Newsstand Prices of Magazines," Journal of Econometrics, No 31, August, pp. 225-274.

8. Hodrick, Robert J. and Prescott, Edward C. (1997) "Postwar U.S. Business Cycles: An Empirical Investigation," Journal of Money, Credit and Banking, vol. 29, No. 1, pp. 1-16.

9. Kormendi, R. C., and Meguir, P. G. (1984) "Cross-Regime Evidence of Macroeconomic Rationality," Journal of Political Economy, vol. 92, pp. 875-908.

10. Kretzmer, Peter E. (1989) "The Cross-Industry Effects of Unanticipated Money in an Equilibrium Business Cycle Model," Journal of Monetary Economics, vol. 23, \# 2, pp. 275-96.

11. Lucas, Robert E. Jr. (1973) "Some International Evidence on Output-Inflation Tradeoffs," The American Economic Review, vol. 63, \# 3.

12. Mishkin, Frederic S. (1983) A Rational Expectations Approach to Macroeconometrics: Testing Policy Ineffectiveness and Efficient-Market Model, The University of Chicago Press.

13. Sargent, Thomas J. and Neil Wallace (1975) "Rational Expectations, the Optimal Monetary Instrument, and the Optimal Money Supply Rule", JPE, vol. 83, \# 2.

14. The U.S. Department of Commerce, Bureau of Economic Analysis, Industry Economics Division (http://www.bea.doc.gov/bea/uguide.htm) 
Notes 